\title{
Shifting The Focus From Teaching To Learning: Rethinking The Role Of The Teacher Educator
}

Amy Hsu, State University of New York College, Old Westbury, USA

Fran Malkin, State University of New York College, Old Westbury, USA

\begin{abstract}
This article will discuss the traditional college format and its recent transformation. It will address the changing role of both the college professor and the $21^{\text {st }}$ century college learner. As society evolves, curriculum develops and new standards are introduced, there is a call for a shift from teacher-directed instruction to student-centered learning. This article specifically highlights strategies for empowering students to take charge of their own learning within the higher education classroom. These techniques include examples for teacher educators to employ as they serve as models to the pre-service teachers they instruct.
\end{abstract}

Keywords: Teacher-Directed Instruction; Student-Centered Learning; Student Empowerment

\section{THE TRADITIONAL COLLEGE FORMAT}

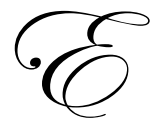

ducation involves the interchange and exchanging of ideas between and among the educator and his/her students. The progression of education at all levels includes both the teaching component and the learning element. These two factors of teaching and learning feed into one another as the educational process takes shape. In institutions of higher education, the focus of classrooms has traditionally been on the teaching or instructional component. That is to say that the conventional role of college faculty is as the lecturer, the expert in his/her field. For more than four decades, education has a long-established practice "of depositing, in which the students are the depositories and the teacher is the depositor" (Freire, 1970, p. 58). This position of the faculty member as "depositor" or transmitter of knowledge places him/her in the principle active role in the instructional process. The students are passive participants, note takers and perceived novices in the field of study. The traditional college classroom is the theater where the professor acts in the lead role and the college students execute their part as spectators of the performance.

The conventional college classroom may be held in a lecture hall with stadium seating and the professor preaching from the podium. The professor is on stage, conveying his/her expertise to the onlookers. The lecture format, though deep rooted in the history of higher education, is not necessarily the most effective way of bridging the teaching and learning factors needed for successful instruction. "Learning unfortunately is not an automatic consequence of pouring information into another person's head. It requires the person's own mental processing. Therefore, lecturing by itself will never lead to real learning" (Silberman, 1996, p. 97). Students are not buckets that merely collect material presented to them. Students' inactive learning approach leads to a great deal of inconsistency and uneasiness about their role in education.

Many educators believe that the traditional lecture approach to teaching is ineffective compared to active learning methods (Jungst, Licklider, \& Wiersema, 2003; Marbach-Ad, Seal, \& Sokolove, 2001). There exists a real need to interact and actively engage with the information presented to best comprehend it. Without a direct interface with the knowledge being introduced, true valuable learning is not being achieved. Students that are working with the new facts and skills in a dynamic fashion are more apt to genuinely comprehend the subject matter. Some research suggests that, compared to the lecture method, methods that promote active learning increase student 
achievement student participation and retention of concepts over time (Berry, 2008; Christianson \& Fisher, 1999; McClanahan \& McClanahan, 2002; O'Sullivan \& Copper, 2003). To further examine the role of students in the education process, it is crucial to carefully investigate who these students are and what in fact motivates them to learn.

\section{COLLEGE STUDENTS TODAY}

What is the population of higher education learners like in the $21^{\text {st }}$ century? Prensky (2001) refers to this group of students as "Digital Natives" and Oblinger \& Oblinger (2005) call them the "Net Generation". Whatever the term, the majority of these individuals were born into the world of technology. They are tech-obsessed, spending the majority of their days staring at computer monitors and tapping on Smartphone screens. The 2011 study conducted by Educause Center for Applied Research (ECAR) on Undergraduate College Students and Information Technology, reported that the majority of participants own more than a dozen technological devices. According to Dahlstrom, de Boor, Grunwald \& Vockley (2011), 87\% of participants own laptops, 70\% ipods and 57\% smartphones. Not only do these students own technological gadgets, but they also report relying on them for academic purposes. While they utilize technology in their world of academia, these learners are far less enthusiastic about their professors' use of technology to advance their educational experience. "Overall, students say their instructors use presentation devices (ie) PowerPoint or presenters) effectively - but devices that inspire participation or interactivity, not so much" (Dahlstrom et al., 2011, p. 24). This directly relates back to the traditional classroom environment where lectures do not call for the interaction between the instructor and his/her students. As educators we must be responsive to our students' needs and wants. The digital learners are accustomed to the fast-paced world of video games and ipad applications. The college class must keep the tempo to engage and inspire the Net Generation. Students are no longer content with sitting back and being spectators of the event, fans of the show. They yearn to be part of the performance, in on the action. One student expressed his/her concerns with conventional college courses. "Classes can get very boring, just reading and taking a quiz, reading, take a quiz. Something, anything, to make it more enjoyable to learn would be wonderful" (Dahlstrom et al., 2011, p.22). Our responsibility, as $21^{\text {st }}$ century educators must be to address the needs of our learners and shift the focus off of our teaching and onto our students' learning.

\section{SHIFTING THE FOCUS}

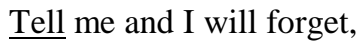

Show me and I may remember,

Involve me and I will understand.

- Confucius, 450 B.C.

Telling students information has not necessarily proven to be a successful measure of communicating content information. Showing students through exhibitions, experiments and demonstrations has been deemed an adequate way of helping some students to recall information. Involving or actively engaging learners was viewed by Confucius (some thousands of years ago) as a means of most effectively and appropriately assisting our learners in retaining the presented information. The involvement Confucius calls for is the same cry $21^{\text {st }}$ century students are expressing in their desire to be involved and engaged in their learning process.

Recently, there has been much discussion about shifting instructional methods in higher education from the traditional teacher-directed lectures to more student-centered, active learning (Bonwell \& Eison, 1991; Prince, 2004). Active learning engages students in a way that they need to participate in meaningful classroom activities, forcing them to think critically about the content of the course. As societies evolve and the roles of both higher education faculty and college students change, engaging and interactive methods of instruction are most critical. As professors in higher education, we must help our students to be flexible and creative problem solvers so that they can excel in life after college. Our students are expected to think critically, solve problems, and work productively with colleagues in each of the various professions they enter. The challenge for educators is to employ strategies that teach course content using the techniques, technology and approaches that engage students as well as help them to develop thinking, problem solving, and life-long learning skills (Savery \& Duffy, 1994). 
These active learning strategies are especially important for teacher educators in higher education who serve as models for the pre-service teachers they instruct. If we want them to teach their future students in a constructivist way, we, as teacher educators, must model this philosophy through our own instruction. Teacher educators must demonstrate our instruction through the way we teach and practice exactly what we preach. We must re-construct the traditional lecture format to meet the needs of our 2012 learners.

\section{TRANSFORMING THE LECTURE FORMAT}

This section includes a description of many different strategies that can help educators to transform their current teaching in order to design more engaging and interactive lessons for their students. Each strategy is general and can be easily adapted to fit lessons in any content area, across the grades from elementary school all the way through graduate level college courses. In addition to a brief description, we also include an example of how we use each technique in our undergraduate and graduate teacher education courses.

\section{Buzz Groups / Think-Pair-Share}

Using Buzz groups, or the Think-Pair-Share strategy, the teacher poses a critical question, and then has students group up or pair to share their ideas, first with each other, and then with the entire class. This strategy has been around for more than four decades. According to Thelen (1970, p. 154), "the buzz group offers a natural and useful transition from the listening situation to the decision of each individual to act. It is an intermediate step in the movement of responsibility from the officials (leaders) to the small groups to the individual." In using this strategy, each student has an opportunity to participate and have his or her ideas heard, even if it is not within the whole group. In addition, the social nature of learning is employed.

\section{Example}

Ask students to discuss (with a partner or a small group) lessons they have observed and which educational philosophies these lessons best represent. After dialogue with their peers, ideas can be brought to the larger group for further discussion.

\section{Quick Writes}

In using Quick Writes, the teacher allows a few minutes for students to respond in writing to something they have just viewed (i.e. a movie clip), heard (i.e. a song), or participated in (i.e. a class activity). In writing, students should include their thoughts, questions, and/or connections to the text that has been presented. This strategy helps students and teachers "find their voices and develop their confidence, as they discover that they have important things to say" (Rief, 2003, p. 8). Every student is given the opportunity to actively reflect on their learning.

Example

Ask students to spend a few minutes writing about their thoughts, questions, and/or connections to the Nesbitt (2007) Vision of K-12 Students Today video or the above-mentioned Confucius quote.

\section{Role Plays}

In using role plays, various roles or parts are assigned to students so that they can put the theory they are learning into practice. This strategy allows students to practice the ideas they are studying. According to Poorman (2002), "integrating experiential learning activities in the classroom increases interest in the subject matter and understanding of course content" (p. 32). Students who role play are forced to think on their feet, while the audience can consider what worked and what didn't in the situation. 


\section{Example}

Role play classroom management situations that may transpire between teacher and students, such as behavioral issues, disruptive learners, apathetic students, and cell phone users.

\section{Anticipation Guides}

Through anticipation guides, teachers provide statements for students to agree or disagree with - this can be done on paper or live where students move along a continuum to show their responses. This introductory strategy activates students' prior knowledge about a topic. "The guide primes the student for concepts, terms, and ideas they may learn, and it hooks their interest and curiosity" (Woelders, 2007, p. 148). By using a live anticipation guide, students are given the opportunity to get up and move around within the classroom. By choosing a space to stand on the continuum, every student is given a voice in this activity.

\section{Example}

Give the students the following two statements: 1) The state should control the individual curriculum for their states. 2) The federal government has the right to impose educational standards on individual states. Have students show their opinions by standing along the continuum.

\section{Graffiti Boards}

In using graffiti boards, students respond to a topic using markers on large newsprint paper to show the concepts they have learned through their graffiti of words, phrases, and pictures. This strategy allows students to respond to a focus point in a creative way. Edwards (2011) writes that graffiti boards allow "even the most reluctant students to share their thoughts on the paper for others to see" (p. 9). All students are given the opportunity to actively participate when this strategy is employed.

\section{Example}

Have students brainstorm the various purposes of education, using words, phrases, symbols, and/or pictures to illustrate their thoughts and opinions.

\section{Consensus Boards}

To participate in consensus boards, students work in groups of four. Each student takes a section of the board (chart paper) where he or she writes about information learned about a topic. After brainstorming individually, students share their ideas in order to reach a group consensus on the top 3 ideas to write in the middle. Short (1996) writes about the importance of this strategy in creating a dialogue among students, where they use their initial responses to eventually consider other perspectives. Another benefit is that while this strategy focuses on the group component where students must work together in forming a consensus, it also has an individual one that allows every student to be heard. In addition, using a consensus board facilitates that assessment of each individual student's understanding, as each one has their own section of the board to complete.

\section{Example}

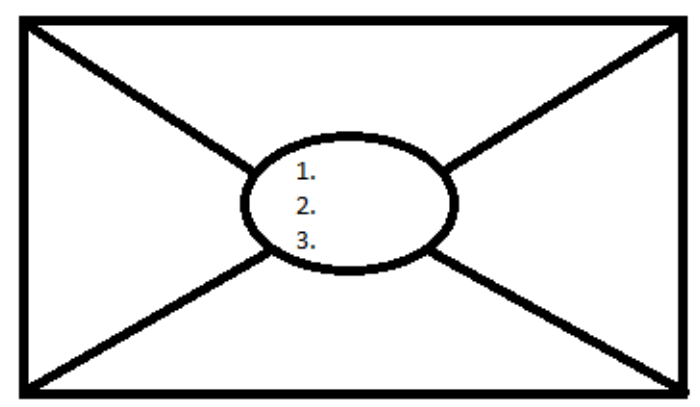


What are the most important ideas about literacy you have learned this semester? Brainstorm your ideas individually on your section of the paper; then share your ideas to reach a group consensus of the three most important ideas you have learned. These should be listed in the center of the consensus board.

\section{Group Reporting / Student Presentations}

Group reporting or student presentations are strategies where small groups of students are assigned topics and specific projects to collaborate on and then share/present/teach/instruct to the rest of the class. According to Springer, Stanne \& Donovan (1997), many students learn best through active, collaborative, small-group work inside and outside the classroom. In presenting information they learned to their peers, students guide the lesson while the professor acts as a facilitator.

\section{Example}

Students prepare a LawQuest presentation on an important educational law. They must include the law as written, an interpretation of the law, a description of two relevant school cases and the final ruling, and a discussion of the implication of the law for schools and teachers.

\section{Graphic Organizers}

In using graphic organizers, students show their understanding of a topic in a diagram (i.e. mind map, Venn diagram, flow chart, web, etc.). This strategy allows students to show their understanding of information in a way that makes sense to them. Daniel (2009) states, "Mapping activities that require learners to process input and then highlight the more important components of text appear to promote higher levels of critical thinking in learners and increase comprehension of text" (p. 139). In addition, "the spatial arrangement of graphic organizers allows the student, and the teacher, to identify missing information or absent connections in one's strategic thinking" (Zollman, 2009 , p. 5). As many of our students struggle with comprehension and organization of content, graphic organizers allow them to better process the information they are learning.

Example

Have students map a web of their interdisciplinary or multicultural thematic unit plan with their topic in the middle, the disciplines they address on the first level, and the activities and lesson ideas on the next level.

\section{Brainstorming and Clustering / List-Group Label}

The brainstorming and clustering or list-group-label strategies ask students to brainstorm ideas on post-it notes (one idea per post-it) and stick them to newsprint paper. The group then cooperatively examines the ideas and clusters them based on similarities. Students then label each group of ideas. This is another strategy that allows the opportunity for all students to participate and actively engages student as they defend their ideas to their peers.

\section{Example}

Students brainstorm ideas on post-it notes about bullying (one idea per post-it). In cooperative groups, they then categorize their ideas, labeling each one (i.e. cyberbullying, personality of a bully, actions of bullies, types of bullying, etc.).

\section{Word Sorts}

In using word sorts, each small group of students is given an envelope with words or ideas that are part of the topic of the day. Students work cooperatively to sort these ideas into groups using their knowledge of the words or ideas. As students create their own categories they demonstrate both mastery of vocabulary and critical thinking skills (Brassell, 2009). Word sorts can be done before the lesson to activate prior knowledge or after the lesson to summarize student understanding and allow students to demonstrate their knowledge of a topic. When participating in a word sort, students are actively engaged as they decide how to group words. 


\section{Example}

Each group receives an envelope with vocabulary related to instructional strategies (i.e. inductive studentcentered learning, problem solving, field trip, investigation, making inferences from data, etc.). Students sort the words into instructional strategy categories (i.e. direct, indirect, experiential, independent study, and interactive).

\section{Visuals / Audio and Video Clips}

In this strategy, materials such as video clips, photographs, physical objects, music, are used to demonstrate specific concepts. According to Berk (2009), "multimedia auditory/verbal and visual/pictorial stimuli increase memory, comprehension, understanding, and deeper learning" (p. 5). These resources grab students' attention in a lesson and help them make connections through media that may be more comfortable for them.

\section{Example}

Show video clips on the new Common Core Standards and Instructional Shifts for ELA and Math and how they are applicable to other disciplinary areas.

\section{THE MODERN COLLEGE FORMAT}

The modern college format is one that focuses on the needs of the students in a particular class at a particular moment in time. The above-described active learning strategies can help to facilitate a complete transformation in college instruction. By using them, traditional roles change and a shift is made where faculty can focus less on their teaching and more on active student learning. In this contemporary format, the faculty takes on the role of a facilitator and coach acting as an advisor to his/her students. At the same time, students shift their focus away from the instructor to concentrate on their own learning where they are active participants and contributors. Both faculty and students are considered co-constructors of knowledge within the classroom environment.

\section{CONCLUSION}

The changing role of both the college professor and the college student is based on our changing society (Light, Cox \& Calkins, 2009). Curriculum is developing, new standards are being introduced, and students today are different than they were years ago. Each of these transformations needs to be addressed in instruction. In the higher education classroom, there is a recent shift from traditional to more progressive, student-centered instructional methods. This revolution is most prevalent in teacher education courses. College faculty must begin to rethink the lecture format and focus on strategies for empowering students to take charge of their own learning. The use of engaging, interactive activities will allow students to take active roles in the educational process.

\section{AUTHOR INFORMATION}

Amy Hsu is an Assistant Professor in the School of Education at SUNY College at Old Westbury. She is a teacher educator, with a strong research interest in literacy and language learning, standardized testing, teacher accountability and professional development. Before becoming a college professor, Dr. Hsu worked as a secondary educator in the public school system. Amy Hsu, Ed.D., School of Education, SUNY College at Old Westbury, Old Westbury, New York, USA. E-mail: hsua@oldwestbury.edu

Fran Malkin is an Assistant Professor in the School of Education at SUNY College at Old Westbury. She is a teacher educator, with a strong research interest in language learning, teacher accountability and professional development. Before becoming a college professor, Dr. Malkin worked as a secondary educator in both public and private school systems. Fran Malkin, Ph.D., School of Education, SUNY College at Old Westbury, Old Westbury, New York, USA. E-mail: malkinf@oldwestbury.edu 


\section{REFERENCES}

1. Berk, R. A. (2009). Multimedia teaching with video clips: TV, movies, YouTube, and mtvU in the college classroom. International Journal of Technology in Teaching and Learning, 5(1), 1-21.

2. Berry, W. (2008). Surviving lecture: A pedagogical alternative. College Teaching, 56, 149-153.

3. Bonwell, C. \& Eison, J. (1991). Active learning: Creating excitement in the classroom. ASHEERIC Higher Education Report No. 1. George Washington University, Washington, DC.

4. Brassell, D. (2009). Dare to differentiate: Vocabulary strategies for all students. New England Reading Association Journal, 44 (2), 1-6.

5. Christianson, R. \& Fisher, K. (1999). Comparison of student learning about diffusion and osmosis in constructivist and traditional classrooms. International Journal of Science Education, 21, 687-698.

6. Dahlstrom, E., de Boor, T., Grunwald, P.,, \& Vockley, M., with a foreword by Diana Oblinger. The ECAR National Study of Undergraduate Students and Information Technology, 2011 (Research Report). Boulder, CO: EDUCAUSE Center for Applied Research, October 2011, available from http://www.educause.edu/ecar.

7. Daniel, M. C. (2009). 'New Frontiers of Literacies: Comprehension at the juncture of the verbal and the visual. International Journal of Learning, 15(10), 139-147.

8. Edwards, A. (2011). "Life is a journey and an iceberg": Creating a context for conceptual thinking. WOW Stories: Connections from the Classroom, 1(2) Retrieved on November 3, 2011 from http://wowlit.org/online-publications/stories/storiesi2/9/

9. $\quad$ Freire, P. (1970). Pedagogy of the oppressed. New York: Herder and Herder.

10. Jungst, S., Licklider, B. \& Wiersema, J. (2003). Providing support for faculty who wish to shift to a learning-centered paradigm in their higher education classrooms. The Journal of Scholarship of Teaching and Learning, 3, 69-81.

11. Light, G., Cox, R. \& Calkins, S. (2009). Learning and teaching in higher education: The reflective practitioner, $2^{\text {nd }} e d$. SAGE Publications, Ltd., London.

12. Marbach-Ad, G., Seal, O. \& Sokolove, P. (2001). Student attitudes and recommendations on active learning. Journal of College Science Teaching, 30, 434-438.

13. McClanahan, E. \& McClanahan, L. (2002). Active learning in a non-majors biology class. College Teaching, 50, 92-96.

14. Nesbitt, B. (2007). A Vision of K-12 Students Today. Video posted to http://www.youtube.com/watch?v= A-ZVCjfWf8

15. O'Sullivan, D. \& Copper, C. (2003). Evaluating active learning: A new initiative for a general chemistry curriculum. Journal of College Science Teaching, 32, 448-452.

16. Oblinger, D. G. and Oblinger, J. L. (2005), Educating the net generation, An Educause e-book publication, http://www.educause.edu/ir/library/pdf/pub7101.pdf [20/04/09]

17. Poorman, P. B. (2002). Biography and role-playing: fostering empathy in abnormal psychology. Teaching of Psychology, 29(1), 32-36.

18. Prenksy, M. (2001). Digital natives, digital immigrants. On the Horizon, 9, 5, 1-6.

19. Prince, M. (2004). Does Active Learning Work? A review of the research. Journal of Engineering Education, 93(3), 223-231.

20. Rief, L. (2003). 100 Quickwrites. New York: Scholastic Teaching Resources

21. Savery, J. \& Duffy, T. (1994). Problem based learning: An instructional model and its constructivist framework. Educational Technology, 35(31-38).

22. Short, K. (1996). Creating classrooms for authors and inquirers. Portsmouth: Heinneman.

23. Silberman, M. (1996). Active learning: 101 strategies to teach any subject. Allyn \& Bacon.

24. Springer, L., Stanne, M. E. and Donovan, S. S., (1997). Effects of small-group learning on undergraduates in science, mathematics, engineering, and technology: a meta-analysis. Research Monograph 11, National Institute for Science Education, University of Wisconsin-Madison.

25. Thelen, H. (1970). Dynamics of groups at work. Chicago: University of Chicago Press.

26. Woelders, A. (2007). "It makes you think more when you watch things": Scaffolding for historical inquiry in the middle school classroom, The Social Studies, 98(4), 145-152.

27. Zollman, A. (2009). Students use graphic organizers to improve mathematical problem-solving communications. Middle School Journal, 41(2), 4-12. 
NOTES 